\title{
6.19 Шляхи впровадження фахових цифрових технологій при підготовіці молодших бакалаврів 3 агрономії
}

Вступ. У статті розглянуто можливі шляхи впровадження у освітній процес вивчення сучасних фахових цифрових технологій на основі існуючих освітньо-професійних програм зі спеціальності 201 «Агрономія», кваліфікаційного рівня «Молодший бакалавр 3 агрономії». Зазначено перелік сучасних цифрових технологій, запропонована можлива структура на основі освітньо-професійної програми для впровадження в освітній процес сучасних фахових цифрових технологій шляхом залучення існуючих інформаційних систем, що використовуються у професійній діяльності. Такий підхід на нашу думку осучаснить освітній процес підготовки молодших бакалаврів аграрного профілю і створить умови одночасного набуття фахових і фахових цифрових компетентностей. Продемонстрований щільний зв'язок освітньо-професійної програми підготовки молодшого бакалавра 3 агрономії і сучасних цифрових технологій. У формі таблиць показаний зв'язок освітніх дисциплін і фахових цифрових технологій, продемонстроване наскрізне представлення фахових цифрових технологій на протязі усього періоду навчання, що у разі залучення, забезпечить неперервне використання фахових інформаційних систем i цифрових технологій. Показана різниця між поняттями «Компетенція» i «Компетентність». Розглянуто складові поняття фахова компетентність. Наведено уточнення поняття цифрова компетентність для молодших спеціалістів з агрономії. Розглянуто напрямки аграрного виробництва, що мають свою реалізацію у сучасних цифрових технологіях. Запропоновано структуру, яка представлена трьома тематичними напрями для охоплення широкого спектру фахових цифрових технологій у агрономії. Аналізуючи зв’язок фахових освітніх дисциплін і цифрових технологій дійшли до висновку що залучення фахових цифрових технологій у освітній процес в більшості потребує зміни освітнього інструменту і використання сучасних цифрових пристроїв, не обмежуючись лише персональним комп’ютером. 
Ключові слова: компетенція, компетентність, агрономія, молодший бакалавр, фахові цифрові технології, фахова цифрова компетентність, освітньопрофесійна програма.

Мета роботи: проаналізувати зв'язок існуючих освітньо-професійних програм молодшого бакалавра з агрономії з існуючими фаховими технологіями

Матеріали і методи: діючі освітньо професійні програми підготовки молодшого бакалавра 3 агрономії, існуючі фахові цифрові технології, порівняльний аналіз

Результати і обговорення: динамічний розвиток цифрових технологій останніх двох десятиліть знайшов своє відображення в усіх сферах людської діяльності, сільське господарство не стало винятком. Тому актуальність нашого дослідження полягає в уточненні поняття «фахова цифрова компетентність» для молодших бакалаврів аграрного профілю. Завданням с аналіз ключового поняття; встановлення зв'язку освітніх програм молодшого бакалавра 3 агрономії з сучасними цифровими технологіями для формування фахової цифрової компетентності.

Досліджуючи поняття «фахова цифрова компетентність», слід зауважити, що у науковій літературі зустрічаються два терміни «компетентність» i «компетенція». Термін «компетенція» використовується у розумінні вимог до знань, умінь і навичок кандидата для виконання професійної діяльності [532]. У свою чергу «компетентність» визначається як особистісна характеристика самої людини [533]. Тобто, оперуючи цими двома термінами, зазначимо, що «компетенція» $є$ критерієм відповідності у певній сфері діяльності, а «компетентність» якісною характеристикою особистості на відповідність визначеним критеріям у діяльності.

Для визначення поняття цифрова фахова компетентність молодшого бакалавра 3 агрономії звернемося до означення фахової компетентності. Формулювання фахової компетенції у більшості досліджень також називають «професійна компетентність» та ототожнюють ці поняття. Питанню дослідження фахової (професійної) компетентності присвячені роботи $\mathrm{H}$. 
Антіпової, I. Гушлевської, В.Ковальчука, Н. Ничкало, G.K. Britell, R.M. Jueger, W.E. Blank та інші.

Підсумовуючи результати досліджень і визначення, можна зробити висновок, що поняття фахової (професійної) компетентності більшість дослідників розуміють як комплексне поняття, не обмежене певним рівнем володіння фахових знань і рівнем професійного досвіду. Воно описує широке коло професійної діяльності, професійної взаємодії фахівця як у колективі, так і використання сучасних професійних технологій задля забезпечення ефективної професійної діяльності на високому професійному рівні, використовуючи актуальні знання і технології.

У дослідженні, присвяченому цифровій компетентності, іiі представляють як взаємодію трьох компонент:

- $\quad$ інформаційна (здатність ефективно працювати з інформацією);

- $\quad$ комп'ютерна або комп’ютерно-технологічна компонента (що визначає уміння та навички роботи з сучасними комп'ютерними засобами та програмним забезпеченням);

- $\quad$ компонента застосовності (яка визначає здатність застосовувати сучасні засоби інформаційних та комп'ютерних технологій до роботи 3 інформацією та розв'язання різноманітних задач) [537].

Наразі, у час широкого розвитку цифрових технологій фахова (професійна) компетентність має бути уточнена на науковому рівні. Адже сучасний фахівець за вимогами часу і ринку праці має володіти необхідним рівнем цифрових навичок, що в свою чергу реалізовують його фахові компетентності. Тому, уточнюючи поняття «фахова компетентність», ми говоримо про фахову цифрову компетентність. Аналізуючи науково-педагогічну літературу, можна зробити висновок, що у напрямі аграрної освіти дослідження фахової цифрової компетентності проводили у вигляді окремих наукових пошуків і воно не представлено у вигляді комплексного наукового дослідження. 
Говорячи про формування фахової цифрової компетентності, слід зазначити найпоширеніші, або ті що мають найбільший попит серед українського аграрного виробництва. Наразі за оцінками фахівців AgTech Ukraine використання цифрових технологій представлено лише у 20-30\% сільськогосподарських підприємств України і найпоширенішими слід виділити: облікові програми, трекінг техніки і пального, дистанційне зондування землі, GPS-обладнання, облік земельного банку, агрометеорологія. Ми у свою чергу пропонуємо, у контексті інтеграції фахових цифрових технологій у освітній процес, розглядати три великі напрями у підготовці здобувачів: Precision Farming - діджиталізація у рослинництві, діджиталізація й автоматизація у сфері агарної техніки й електротехніки, Інформаційні системи управління у сільському господарстві (FMIS) [538.]. Опираючись на запропоновані напрями, ми провели дослідження, де спробували дослідити зв'язок зазначених напрямів і типових для спеціальності 201 «Агрономія» освітніх дисциплін. Згідно з нашим аналізом, який грунтувався на зв'язку освітніх дисциплін із сучасними цифровими технологіями, існує щільний зв'язок, що в більшості освітньо-професійних програм рівномірно розподілений впродовж усього періоду навчання за винятком окремих освітніх програм, де вивчення фахових дисциплін починається з другого року навчання. Аналіз відповідності проводили на основі освітньо-професійних програм «Агрономія», спеціальності 201 «Агрономія», освітньо-кваліфікаційного рівня «Молодший бакалавр з агрономії» за період 2019-2020 pp. 
Таблиця 1.

Зв’язок освітніх дисциплін і фахових цифрових технологій в освітньому

процесі

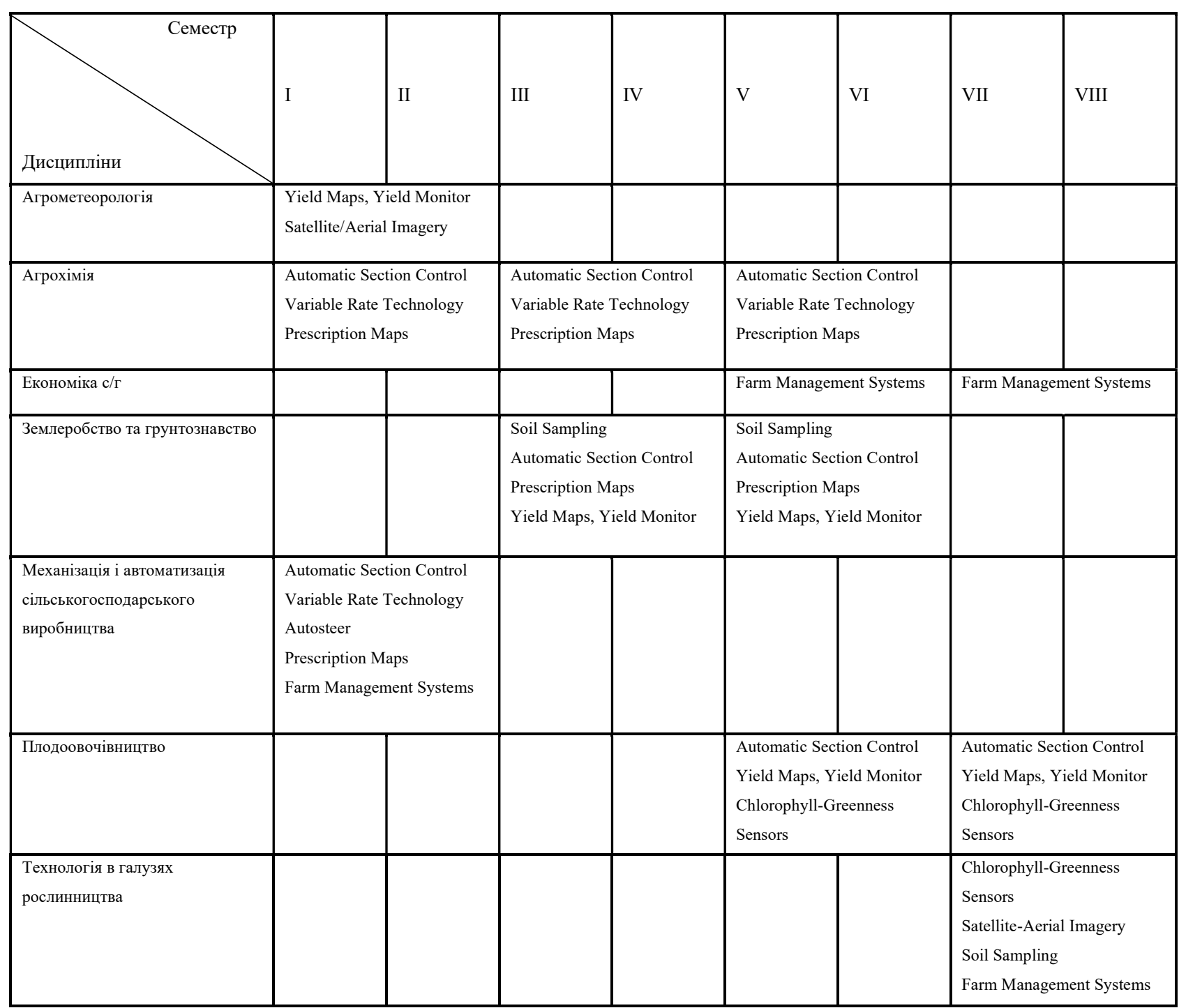

Існування зв'язку між фаховими цифровими технологіями і фаховими освітніми дисциплінами зрозуміло, тому у процесі аналізу ми спробували розглянути, яка щільність залучення фахових цифрових технологій, які ми прив'язуємо до освітніх дисциплін у освітньому процесі. Наступна таблиця демонструє, що залучати фахові цифрові технології можливо на протязі усього освітнього процесу, а деякі технології представлені практично в усіх семестрах. 
Таблиця 2. .

Щільність можливого представлення цифрових технологій у освітньому процесі

\begin{tabular}{|l|l|l|l|l|l|l|l|l|}
\hline $\begin{array}{l}\text { Lифрові Семестр } \\
\text { технологіi }\end{array}$ & I & II & III & IV & V & VI & VII & VIII \\
\hline $\begin{array}{l}\text { Yield Maps, Yield } \\
\text { Monitor }\end{array}$ & + & + & + & + & + & + & + \\
\hline $\begin{array}{l}\text { Soil Sampling } \\
\text { Shlorophyll/Greenness }\end{array}$ & & & + & + & + & + & + \\
\hline Satellite/Aerial Imagery & + & + & & & & & + \\
\hline $\begin{array}{l}\text { Farm Management } \\
\text { Systems }\end{array}$ & + & + & & & + & + & + \\
\hline $\begin{array}{l}\text { Variable } \\
\text { Technology }\end{array}$ & + & + & + & + & + & + & + \\
\hline $\begin{array}{l}\text { Automatic Section } \\
\text { Control }\end{array}$ & + & + & + & + & + & + & + \\
\hline Autosteer rate & + & + & & & & & \\
\hline Prescription Maps & + & + & + & + & + & + & \\
\hline
\end{tabular}

Аналізуючи далі ми спробували вияснити, який відсоток тем у освітніх дисциплінах перетинається з фаховими цифровими технологіями і згідно нашого аналізу перетин тем у робочих навчальних програмах склав від 8\% до 69\%.

Впровадження у освітній процес вивчення фахових цифрових технологій потребує використання певного набору освітніх інструментів, тому на нашу думку доцільно використовувати сучасні інформаційні системи які базуються на фахових цифрових технологіях. Такими інструментами можуть бути існуючі інформаційні системи, для прикладу можна навести Softfarm i AgroOnline, що мають широкий набір відповідних інструментів.

Висновки: поширення цифрових технологій, зокрема фахових, створило умови, які дають можливість осучаснити освітній процес і змінити освітній інструмент. Аналіз, що показує щільний зв'язок фахових цифрових технологій 3 освітніми дисциплінами, - це наслідок того, що аграрне виробництво потребувало впровадження цифрових технологій. Тому сучасний освітній процес також потребує змін, що передбачають впровадження фахових цифрових 
компетентностей. Слід зауважит, що впровадження цифрових технологій в освітній процес закладів освіти аграрного профілю сьогодні відбуваєтьсь не зважаючи на пандемію Covid19 про що свідчить робота проекту FABU «Сприяння розвитку професійної освіти в аграрних коледжах України» [539]. 